\title{
Investigation of soil quality and heavy metal concentrations from a waste dumping site of Konabari industrial area at Gazipur in Bangladesh
}

\author{
${ }^{1}$ Md. Sirajul Islam, ${ }^{2}$ Tanmoy Roy Tusher, ${ }^{3}$ Mahbuba Mustafa, \\ ${ }^{4}$ Shamim Al Mamun \\ ${ }^{1,2,3,4}$ Department of Environmental Science and Resource Management, Mawlana Bhashani Science and \\ Technology University, Tangail-1902, Bangladesh
}

\begin{abstract}
The study was conducted to determine the soil pollution from the downstream area of the waste dumping site in relation to changes in soil quality as well as chemical characteristics and heavy metals concentrations in Konabari industrial area of Bangladesh, during the period from July to December 2011. Soil samples were collected from five different points at a distance of $10 \mathrm{~m}$ from each other. Samples were collected from two layers i.e. from surface and subsurface at a depth of 0-15 and 15-30 cm, respectively. The study concluded that the waste material produced tangible impacts on the soil quality, while the samples contained higher available sulphur $(S)$, but lower total nitrogen $(N)$, available phosphorus $(P)$ and organic matter $(O M)$ contents. The dumping of waste resulted in a marked increase in the concentration of heavy metals in soils, and the measured metals varied in the order of iron $(\mathrm{Fe})>$ zinc $(\mathrm{Zn})>$ lead $(\mathrm{Pb})>\operatorname{copper}(\mathrm{Cu})>\operatorname{cadmium}(\mathrm{Cd})$. The mean concentrations of the selected heavy metals in the surface soil of the dumped site were 0.40, 1.42, $0.46,350.38$ and $0.03 \mathrm{ppm}$ for $\mathrm{Cu}, \mathrm{Zn}, \mathrm{Pb}, \mathrm{Fe}$ and $\mathrm{Cd}$, respectively, while the mean concentrations of the heavy metals in the subsurface soil were 0.39, 1.36, 0.47, 313.3 and 0.03 ppm for $\mathrm{Cu}, \mathrm{Zn}, \mathrm{Pb}, \mathrm{Fe}$ and $\mathrm{Cd}$, respectively. This could be attributed to the leachates percolated from the wastes. The metal species were found comparatively lower on the solid waste accumulation site and higher on the industrial effluents accumulation site. Such a condition could be regarded as unsafe as these heavy metals are eventually picked up by growing plants and thereby entering the food chain. So, careless disposal of the waste should be discouraged, and a waste management and treatment policy should be put in place for the waste dumping and/or disposal.
\end{abstract}

Keywords: Soil quality, heavy metal, waste dumping, industrial area.

\section{Introduction}

The rapid growth of industrialization and urbanization decreases the non-renewable resources and disrupts the natural environment through indiscriminate disposal of solid waste, industrial effluents and other toxic wastes which the major environmental issues are posing threats to the existence of human being. Waste is one of the most visible, immediate and serious environmental problems in developing countries like Bangladesh [1]. General municipal solid waste is collected and dumped in a mixed form in an unscientific manner on open waste land or low lying areas even near creeks, forests, rivers, ponds and other ecological sensitive regions, resulting in serious environmental pollution [2].

Industrial activities are also identified as a major cause for metal contamination of the ecosystem and are largely responsible for the growing amount of pollutants in the soil $[3,4,5,6]$. Depending on the type of industrial activities, huge amount of industrial disposal is produced. Due to lack of properly equipped plants and sanitary dumping sites operated within the required standards, the industrial wastes are released in an adhoc manner to the environment. When the waste stream typically contains a complex mixture of toxic substances predominantly natural and synthetic organic substances, metals, and trace elements, as well as pathogens from domestic and industrial sectors enter into lakes, streams, rivers, ocean, and other water bodies, they get dissolved or lie suspended in water bodies or lie suspended in water or get deposited on the bed [7]. Presently $10 \%$ of the waste water generated is being treated; the rest is discharged as it is into our water bodies [8].

During the monsoon season, the river water floods the land and contaminates reach the soil. Several industries dump their unwanted waste in soil. These waste products include harmful substances such as plastic materials, bottles, broken pieces of metal, radioactive wastes, magnesium sulphate, chemicals, powders, and a lot more. These waste products adversely affect the intrinsic nature of soil and bring about an imbalance. Solid waste leachate which is the greatest threat to groundwater possesses various chemical and biological contaminants $[9,10,11]$. The burning of these wastes gets rid of the organic materials leaving the metal contents. After the process of oxidation and corrosion, these metals dissolve in rainwater and leach into the soil from where they are taken up by plants and subsequently get into the food chain [12]. Almost any material will produce leachate if water is allowed to percolate through it. The quality of leachate is determined primarily by 
the composition and solubility of the waste constituents [13]. Produced leachate essentially contains elements such as potassium, nitrogen, heavy metals and organic compositions [14].

Heavy metals released from industries are kept under environment pollutant category due to their toxic effects on plants, animals and human beings. They interfere with physiological activities of plants such as photosynthesis, gaseous exchange and nutrient absorption and cause reduction in plant growth, dry matter accumulation and yield [15]. Thus, concern over the possible ecological effect of the increasing accumulation of metallic contaminants in the environment is growing. For this reason, the investigation of heavy metals in soil is essential since even slight changes in their concentration above the acceptable levels can result in serious environmental and subsequent health problems [16]. The study was conducted to investigate the soil quality, especially the heavy metal concentrations, in and downstream of the waste dumping site at the Konabari industrial zone, Gazipur, Bangladesh.

\section{Materials and Methods}

\section{Study Area}

The study area was located at the Konabari BSCIC (Bangladesh Small and Cottage Industries Corporation) area at Gazipur district adjacent to the capital city Dhaka of Bangladesh, which is approximately at the latitude of $24.00^{\circ} \mathrm{N}$ and longitude $90.34^{\circ} \mathrm{E}$ (Fig. 1). The elevation of the area was approximately 10 meters and situated beside the Tangail-Gazipur highway. This area is geographically a part of the pleistocene terrace, popularly known as Madhupur tract which composed of alluvial soil of the pleistocene period. Such lands are characterized by high, undulated land surface with red soil, criss crossed by flood plains and streams. The Turag River is flowing through the study area. The Turag River is flowing through the study area. The study area is a unique place where industrial effluents are directly discharged through different channels into the river which causes the continuous pollution of water, and also solid wastes are dumped regularly on the bank of the river in an unscientific manner. During the monsoon, these solid wastes are flowed and flooded through the river and the surrounding land areas, respectively, which not only disrupt the water quality of the river but also the surrounding soil quality.

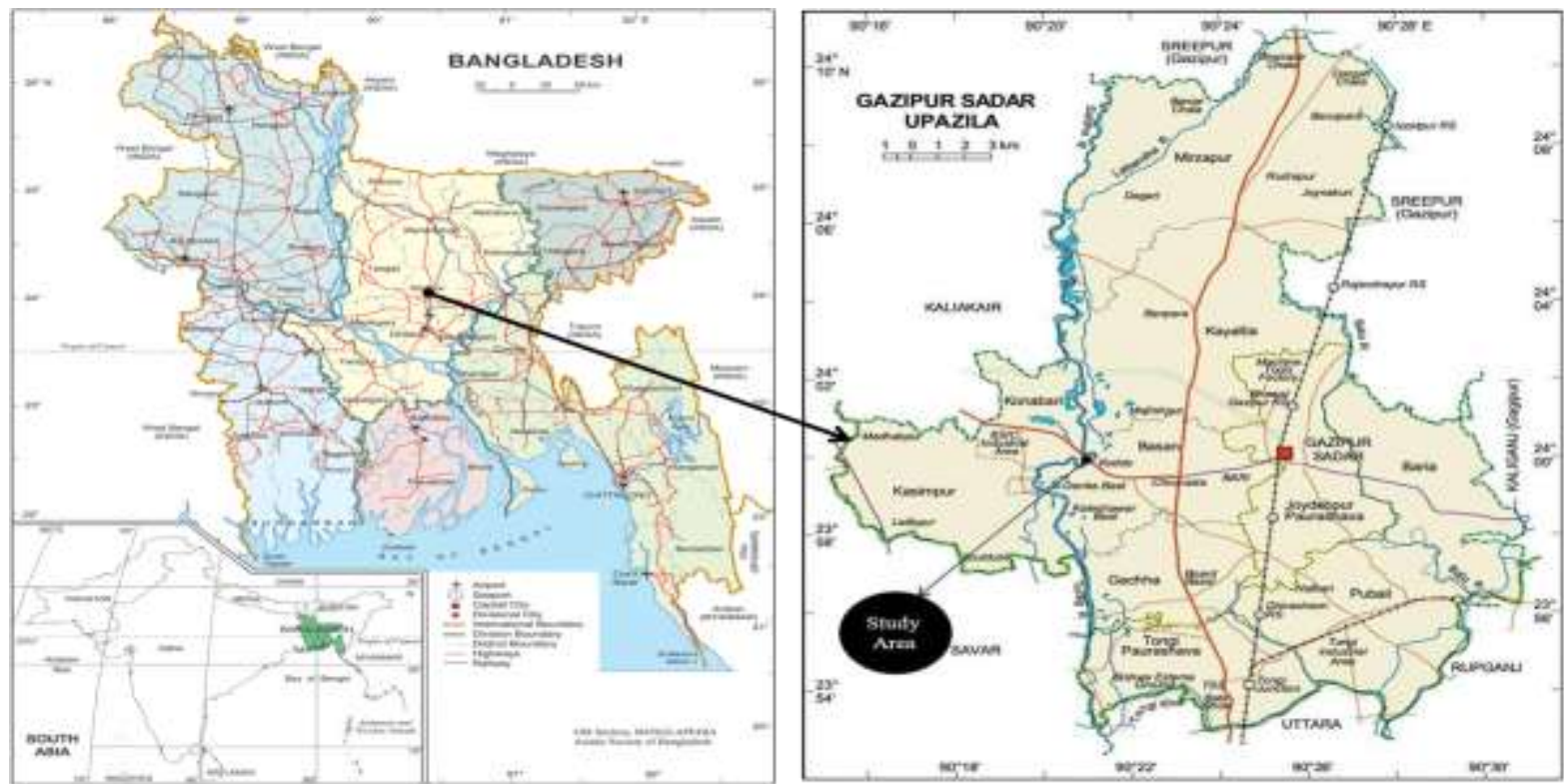

Fig. 1. Map showing the study area at Konabari industrial area of Gazipur in Bangladesh. Source: Banglapedia [17]

\section{Sampling}

Ten soil samples were collected from five different points at a distance of $0,10,20,30$ and $40 \mathrm{~m}$ from the solid waste dumping site. Among them five samples $\left(\mathrm{P}_{1-1}, \mathrm{P}_{2-1}, \mathrm{P}_{3-1}, \mathrm{P}_{4-1}\right.$ and $\left.\mathrm{P}_{5-1}\right)$ were collected from surface at 0-15 cm depth and rest of the five $\left(\mathrm{P}_{1-2}, \mathrm{P}_{2-2}, \mathrm{P}_{3-2}, \mathrm{P}_{4-2}\right.$ and $\left.\mathrm{P}_{5-2}\right)$ from subsurface soil at 15-30 cm depth (Table 1). The layout of the study area with sampling points is shown in the Fig. 2. The samples were scraped from the top to bottom with the help of an auger. Each samples were kept separately on a brown paper and contents of each brown paper were mixed thoroughly. Then about $1 \mathrm{~kg}$ of soils was collected from each paper to give a representative sample. Samples were placed in sealed polythene bags and lebeled including date of collection, location and code number of soil sample. The samples were then carried to the Environmental Biology Lab of the Department of Environmental Science and Resource Management of the University 
(MBSTU), Tangail-1902, Bangladesh. From the collected samples, the gravels, pebbles, plant roots, leaves, etc. were picked up and removed. The collected soil samples were dried in air for a period of 7 days by spreading on a clean piece of paper, and then the samples were mixed well and ground to pass through a $2 \mathrm{~mm}$ mesh stainless steel sieve. The soil samples were kept in a clean polythene bag and then transported to the Bangladesh Institute of Nuclear Agriculture (BINA), Mymensingh-2202, Bangladesh, for the analysis of soil pH, electrical conductivity (EC), organic matter $(\mathrm{OM})$, available $\mathrm{P}$, available $\mathrm{S}$, total $\mathrm{N}$ and heavy metals as well as $\mathrm{Cu}, \mathrm{Zn}$, $\mathrm{Pb}, \mathrm{Fe}$ and $\mathrm{Cd}$.

Table 1. Sample Collection Points in the Study Area

\begin{tabular}{ccccc}
\hline Sampling points & Replications & $\begin{array}{c}\text { Distance from solid waste } \\
\text { dumping site }(\mathrm{m})\end{array}$ & $\begin{array}{c}\text { Soil depth } \\
(\mathrm{cm})\end{array}$ & Soil layer \\
\hline $\mathrm{P}_{1}$ & $\mathrm{P}_{1-1}$ & 0 & $0-15$ & Surface \\
& $\mathrm{P}_{1-2}$ & 0 & $15-30$ & Subsurface \\
\hline $\mathrm{P}_{2}$ & $\mathrm{P}_{2-1}$ & 10 & $0-15$ & Surface \\
& $\mathrm{P}_{2-2}$ & 10 & $15-30$ & Subsurface \\
\hline $\mathrm{P}_{3}$ & $\mathrm{P}_{3-1}$ & 20 & $0-15$ & Surface \\
& $\mathrm{P}_{3-2}$ & 20 & $15-30$ & Subsurface \\
\hline $\mathrm{P}_{4}$ & $\mathrm{P}_{4-1}$ & 30 & $0-15$ & Surface \\
& $\mathrm{P}_{4-2}$ & 30 & $15-30$ & Subsurface \\
\hline $\mathrm{P}_{5}$ & $\mathrm{P}_{5-1}$ & 40 & $0-15$ & Surface \\
& $\mathrm{P}_{5-2}$ & 40 & $15-30$ & Subsurface \\
\hline
\end{tabular}

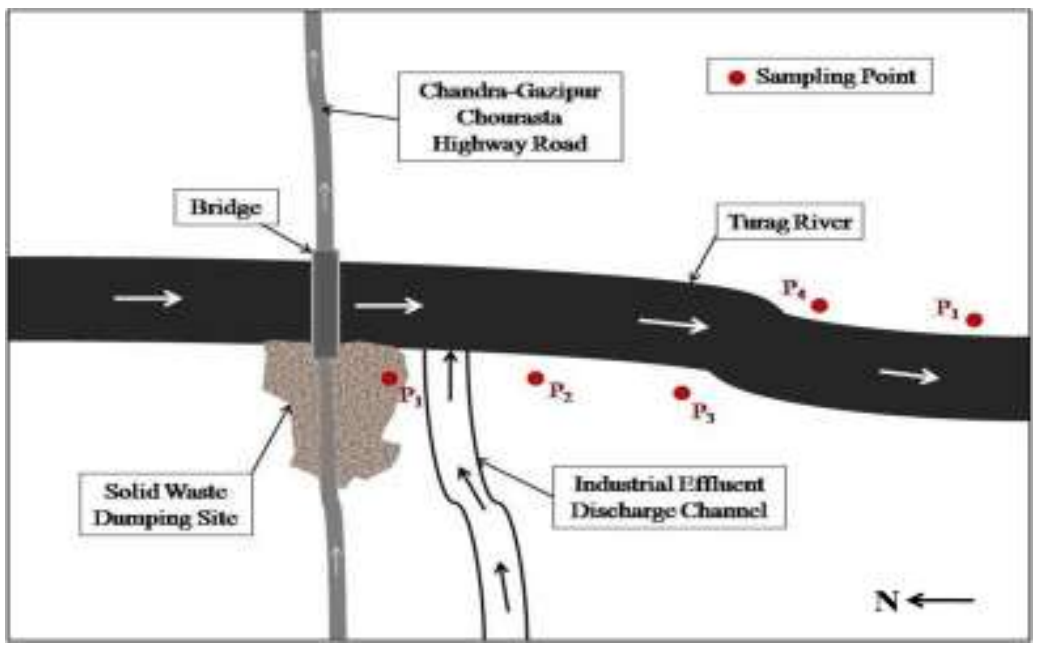

Fig. 2. Layout of the study area with sampling points in Konabari industrial area, Gazipur, Bangladesh.

\section{Sample Analysis}

Various standard methods were followed and a number of sophisticated instruments were used during the analysis of soil samples. The soil $\mathrm{pH}$ was determined by glass electrode $\mathrm{pH}$ meter at a soil: water ratio of 1:2.5 as described by Jackson [18]. EC was measured by conductivity meter in 1:5 ratio of soil water suspension [19]. The OM of the each soil sample was determined by Walkley and Black's wet oxidation method as outlined by Jackson [18]. The OM content was calculated by multiplying the content of organic carbon (OC) by Van Bemmelen's factor 1.73 [20]. Available $\mathrm{P}$ was extracted by Olsen's method $\mathrm{SnCl}_{2}$ as reducting agent. The extract was estimated colorimetrically following the blue color method and was analyzed by a spectrophotometer at $660 \mathrm{~nm}$ wavelength [21]. Available $\mathrm{S}$ was determined by Turbidimetric method with the help of a spectrophotometer. $\mathrm{CaCl}_{2}$ solution $(0.15 \%)$ was used for the extraction of soil [22]. The amount of $\mathrm{S}$ in the extract was estimated turbidimetrically by spectrophotometer at $420 \mathrm{~nm}$ wavelength [18]. Total $\mathrm{N}$ in the soil was determined by semi-micro Kjeldahl method by digesting soil sample with concentrated $\mathrm{H}_{2} \mathrm{SO}_{4}$ and catalyst mixture $\left(\mathrm{K}_{2} \mathrm{SO}_{4}: \mathrm{CuSO}_{4} \cdot 5 \mathrm{H}_{2} \mathrm{O}: \mathrm{Se}=10: 1: 0.1\right)$. The $\mathrm{N}$ in the digest was estimated by distillation with $40 \%$ $\mathrm{NaOH}$ followed by titration of the distillate trapped in boric acid with $0.01 \mathrm{~N} \mathrm{H}_{2} \mathrm{SO}_{4}$ [22]. All the elements, i.e. $\mathrm{Cu}, \mathrm{Cd}, \mathrm{Fe}, \mathrm{Pb}$ and $\mathrm{Zn}$ in soil, were determined with the help of Atomic Absorption Spectrophotometer (AAS) followed the procedure of McLaren et al. [23]. The wavelengths of $\mathrm{Cu}, \mathrm{Fe}, \mathrm{Pb}, \mathrm{Zn}$ and $\mathrm{Cd}$ were 324.8, 248.3, 217.0, 213.9 and $228.8 \mathrm{~nm}$, respectively. After laboratory analysis of the samples, data was analyzed using Statistical Package for Social Sciences (SPSS) and Microsoft office excel. 


\section{Results and Discussions}

The soil $\mathrm{pH}$ of the samples was ranged from 6.10 to 6.98 and 6.10 to 6.94 in the surface and subsurface soils, respectively (Table 2). The trend of $\mathrm{pH}$ was found inconsistent among the different sampling points near or far from the waste dumping site. With increase in soil depth, the $\mathrm{pH}$ was found to be decreased in the collected samples. Different factors like leaching action of wastes, soil nature, mechanical composition, etc. may be responsible for the decrease in $\mathrm{pH}$ [24]. The $\mathrm{pH}$ of most of the soil samples were within the range of the optimum soil $\mathrm{pH}$ (6.5-7.0) for crop production [25].

Table 2. The $\mathrm{pH}$ and Electrical Conductivity from Soil at Different Sampling Points

\begin{tabular}{ccccccccccccc}
\hline \multirow{2}{*}{$\begin{array}{c}\text { Soil } \\
\text { parameters }\end{array}$} & \multicolumn{1}{c}{$\mathrm{P}_{1}$} & \multicolumn{1}{c}{$\mathrm{P}_{2}$} & \multicolumn{4}{c}{ Sampling points } & $\mathrm{P}_{3}$ & \multicolumn{1}{c}{$\mathrm{P}_{4}$} & $\mathrm{P}_{5}$ & \multicolumn{2}{c}{ Mean \pm SD } \\
\cline { 2 - 12 } & $\mathrm{P}_{1-1}$ & $\mathrm{P}_{1-2}$ & $\mathrm{P}_{2-1}$ & $\mathrm{P}_{2-2}$ & $\mathrm{P}_{3-1}$ & $\mathrm{P}_{3-2}$ & $\mathrm{P}_{4-1}$ & $\mathrm{P}_{4-2}$ & $\mathrm{P}_{5-1}$ & $\mathrm{P}_{5-2}$ & Surface & Subsurface \\
\hline $\mathrm{pH}$ & 6.90 & 6.52 & 6.98 & 6.94 & 6.97 & 6.69 & 6.47 & 6.20 & 6.10 & 6.10 & $6.68 \pm$ & $6.49 \pm 0.35$ \\
& & & & & & & & & & & 0.39 & \\
EC $(\mathrm{mS} / \mathrm{cm})$ & 434 & 224 & 142 & 720 & 845 & 352 & 247 & 192 & 216 & 187 & $633.20 \pm$ & $335.00 \pm 225.38$ \\
& & & 4 & & & & & & & & 508.21 & \\
\hline
\end{tabular}

Note: $\mathrm{SD}=$ Standard deviation

The $\mathrm{pH}$ and $\mathrm{EC}$ of the soils are indicators of the background chemical matrices of the soils, and they may be, over the long run, affected by the water quality, organic and inorganic inputs etc. The EC of the samples increased from 216 to $1424 \mathrm{mS} / \mathrm{cm}$ in the surface soils and from 187 to $720 \mathrm{mS} / \mathrm{cm}$ in the subsurface soils (Table 2). The study revealed that the EC of the downstream soils receiving industrial effluents was higher than the soils affected by solid wastes, and the value of EC is decreasing with decreasing the influence of industrial effluents. The presence of large amount of ionic substance and soluble salts have resulted in increased value of EC in the industrial effluents treated soil samples in comparison to the others. High value of EC can be toxic to plants and may prevent them from obtaining water from soil [24].

The OM content of the soils was found to be ranged from 0.60 to $1.19 \%$ in the surface soils and from 0.26 to $0.86 \%$ in the subsurface soils. The study found that value of OM content in surface soil is decreasing with increasing the distance from the dumping site of industrial effluents, while inconsistency was found in subsurface soils (Fig. 3). On the other hand, the total $\mathrm{N}$ content in the surface soils were ranged from 0.07 to $0.10 \%$, while in the subsurface soils were from 0.04 to $0.07 \%$ (Fig. 4). The result found that the total $\mathrm{N}$ content decreased with increasing the depth of soils. The soil of the study area contained very low OM and total $\mathrm{N}$ contents for crop production [26].

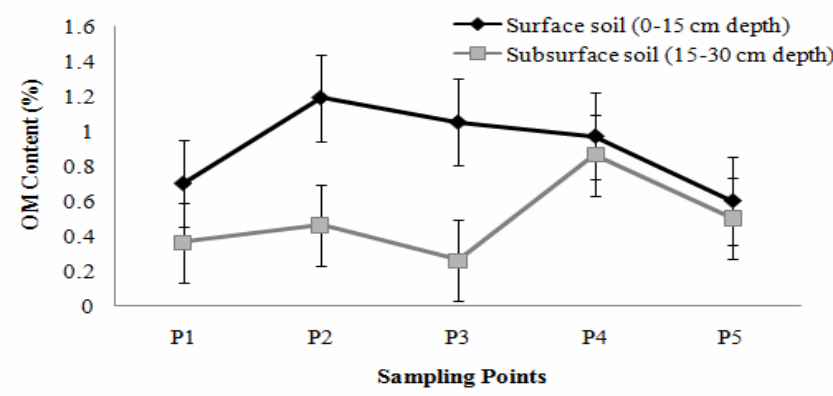

Fig. 3. Status of organic matter (OM) content in soil at different sampling points.

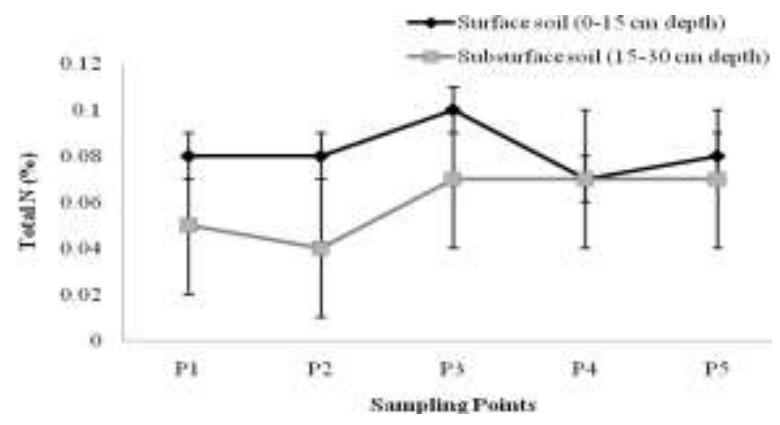

Fig. 4. Status of total $\mathrm{N}$ content in soil at different sampling points. 
The available P content of the study area was found to be ranged from 4.89 to $11.74 \mathrm{ppm}$ in the surface soils and 5.01 to $14.80 \mathrm{ppm}$ in the subsurface soils (Table 3). The results of the study revealed that the highest available $\mathrm{P}$ content in soils was recorded in solid waste dumping site than that of others. The soil of the study area contained low $\mathrm{P}$ content for crop production [26]. A severely high accumulation of $\mathrm{S}$ in the soils was measured from the study area. The concentrations of available $\mathrm{S}$ were recorded ranging from 51.96 to 278.75 ppm in the surface and 11.11 to $265.35 \mathrm{ppm}$ in the subsurface soils (Table 3). The study also found that the $\mathrm{S}$ contents in soils increased significantly due to the application of industrial effluents and the content decreased with increasing both the distance and depth.

Table 3. Soil Quality Parameters in Waste Dumping Site of the Study Area

\begin{tabular}{|c|c|c|c|c|c|c|c|c|c|c|c|c|}
\hline \multirow{3}{*}{$\begin{array}{c}\text { Soil } \\
\text { parameters } \\
(\mathrm{ppm})\end{array}$} & \multicolumn{10}{|c|}{ Sampling points } & \multirow{2}{*}{\multicolumn{2}{|c|}{ Mean \pm SD }} \\
\hline & \multicolumn{2}{|c|}{$\mathrm{P}_{1}$} & \multicolumn{2}{|c|}{$\mathrm{P}_{2}$} & \multicolumn{2}{|c|}{$\mathrm{P}_{3}$} & \multicolumn{2}{|c|}{$\mathrm{P}_{4}$} & \multicolumn{2}{|c|}{$\mathrm{P}_{5}$} & & \\
\hline & $P_{1-1}$ & $\mathrm{P}_{1-2}$ & $\mathrm{P}_{2-1}$ & $\mathrm{P}_{2-2}$ & $\mathrm{P}_{3-1}$ & $\mathrm{P}_{3-2}$ & $\mathrm{P}_{4-1}$ & $\mathrm{P}_{4-2}$ & $\mathrm{P}_{5-1}$ & $\mathrm{P}_{5-2}$ & Surface & Subsurface \\
\hline Available & 11.7 & 14.8 & 7.09 & 5.26 & 6.36 & 5.01 & 4.89 & 8.19 & 6.11 & 6.11 & $7.24 \pm$ & $7.87 \pm$ \\
\hline $\begin{array}{l}\text { Phosphorus } \\
\text { (P) }\end{array}$ & 4 & 0 & & & & & & & & & 2.63 & 4.07 \\
\hline Available & 127. & 30.0 & 278.7 & 134.3 & 275.4 & 265.3 & 238.2 & 146. & 236. & 134. & 231.24 & $142.04 \pm$ \\
\hline Sulphur (S) & 12 & 6 & 5 & 1 & 9 & 5 & 3 & 17 & 60 & 31 & \pm 61.51 & 83.49 \\
\hline Copper $(\mathrm{Cu})$ & 0.20 & 0.18 & 0.51 & 0.62 & 0.50 & 0.53 & 0.47 & 0.41 & 0.32 & 0.21 & $\begin{array}{c}0.40 \pm \\
0.14\end{array}$ & $\begin{array}{c}0.39 \pm \\
0.19\end{array}$ \\
\hline Zinc $(\mathrm{Zn})$ & 1.08 & 0.96 & 1.68 & 1.68 & 1.58 & 1.56 & 1.49 & 1.55 & 1.29 & 1.07 & $\begin{array}{c}1.42 \pm \\
0.24\end{array}$ & $\begin{array}{c}1.36 \pm \\
0.33\end{array}$ \\
\hline Lead $(\mathrm{Pb})$ & 0.36 & 0.43 & 0.56 & 0.29 & 0.52 & 0.56 & 0.50 & 0.53 & 0.37 & 0.42 & $\begin{array}{c}0.46 \pm \\
0.09\end{array}$ & $\begin{array}{c}0.47 \pm \\
0.11\end{array}$ \\
\hline Iron $(\mathrm{Fe})$ & $\begin{array}{c}273 . \\
4\end{array}$ & $\begin{array}{c}416 . \\
1\end{array}$ & 395.4 & 279.3 & 392.9 & 342.4 & 369.4 & $\begin{array}{c}320 . \\
8\end{array}$ & $\begin{array}{c}320 . \\
8\end{array}$ & $\begin{array}{c}207 . \\
9\end{array}$ & $\begin{array}{r}350.38 \\
\pm 52.43\end{array}$ & $\begin{array}{c}313.30 \pm \\
77.03\end{array}$ \\
\hline $\begin{array}{l}\text { Cadmium } \\
(\mathrm{Cd})\end{array}$ & 0.01 & 0.03 & 0.04 & 0.05 & 0.04 & 0.04 & 0.03 & 0.03 & 0.02 & 0.01 & $\begin{array}{c}0.03 \pm \\
0.01\end{array}$ & $\begin{array}{c}0.03 \pm \\
0.02\end{array}$ \\
\hline
\end{tabular}

Note: $\mathrm{SD}=$ Standard deviation

Govil et al. [27] stated that industrialization and urbanization are the two main causes for the increasing contamination of heavy metals in soils. The continuous dumping of both the municipal and industrial waste in the study area resulted in a marked increase in the concentration of heavy metals in soils. The measured metal contents in the soils varied in the order: $\mathrm{Fe}>\mathrm{Zn}>\mathrm{Pb}>\mathrm{Cu}>\mathrm{Cd}$. The concentrations of $\mathrm{Cu}$ were recorded ranging from 0.20 to 0.51 and 0.18 to $0.62 \mathrm{ppm}$ in the surface subsurface soils, respectively (Table 3 ). Though copper is a micronutrient of prime importance in agricultural production, it may cause environmental problem when accumulated in soils [28].

The $\mathrm{Zn}$ contents of the study area were found to be ranged from 1.08 to $1.68 \mathrm{ppm}$ in the surface and 0.96 to $1.68 \mathrm{ppm}$ in the subsurface soils (Table 3 ). The study also showed that there was nearly same amount of $\mathrm{Zn}$ contents in both the surface and subsurface soils of the study area, which might be due to leaching of $\mathrm{Zn}$ contents to the soils. Moon et al. [29] found that $\mathrm{Zn}$ concentration in effluent of industries increased soil $\mathrm{Zn}$ status, but this might be changed by rains. The $\mathrm{Pb}$ contents of the study area were ranged from 0.36 to 0.56 and 0.29 to $0.56 \mathrm{ppm}$ in the surface and subsurface soils, respectively, while the concentrations of Fe were found to be ranged from 273.4 to $395.4 \mathrm{ppm}$ in the surface and 207.9 to $416.1 \mathrm{ppm}$ in the subsurface soils (Table 3). Increased amount of iron may be contributed by the weathering of rocks and also by the discharge of effluent and other wastes on surface that percolated into the ground water [30]. The soil of the study area contained much higher amount of Fe contents [26].

The Cd contents were ranged from 0.01 to $0.04 \mathrm{ppm}$ in surface and 0.01 to $0.05 \mathrm{ppm}$ in subsurface soils, respectively (Table 3). Cadmium dispersed in the environment persists in soils and sediments for decades and taken up by plants which accumulates in the biosphere [31]. Although the concentration trend of $\mathrm{Cd}$ in the soils was found lowest as compared to the other elements, it was obvious that industries effluents were highly responsible for not only the increase in $\mathrm{Fe}$ content in the soil but also cause an increase in $\mathrm{Zn}, \mathrm{Pb}, \mathrm{Cu}$ and $\mathrm{Cd}$ contents. Barman et al. [32] and Xiong et al. [33] also reported that the higher amounts of heavy metals like $\mathrm{Cu}$, $\mathrm{Zn}, \mathrm{Fe}, \mathrm{Pb}$ and $\mathrm{Cd}$ were recorded in the irrigated soil near industrial complex. Similar results were also recorded by Zahid et al. [34].

The results of the study indicated that the heavy metal contents in soils increased significantly with high accumulation in the subsurface soils due to the application of industrial effluents than that of the solid waste. Leaching of these heavy metal contents to the soils during the monsoon might be the cause of high accumulation of metals in the subsurface soils, which have been well documented to have negative impact on 
plant growth. Excessive accumulation of heavy metals such as $\mathrm{Cu}, \mathrm{Zn}, \mathrm{Cd}$ and $\mathrm{Pb}$ in the soils due to effluent discharge and the resultant phytotoxicity was also reported by Peralta et al. [35] and Tsakou et al. [36].

\section{Conclusion}

The study concluded that the industrial effluent has much negative impact on the downstream soils than the solid waste. The $\mathrm{pH}$ of the soil was neutral and suitable for agriculture, while the $\mathrm{OM}$, total $\mathrm{N}$ and available $\mathrm{P}$ were much lower than the standard level for crop production [26]. That is, the soil of the study area was not suitable for crop production. Several years before local people cultivated many crops such as rice, peanut, mustard, potato, etc. in this area, but now-a-day they do not cultivate those types of crops here due to less production. The results of the study also revealed that both the surface and subsurface soils contained higher heavy metal concentrations. Therefore, this indiscriminate dumping of waste into the soil and leaching from the waste dumping site is obviously detrimental for human being as they are not biodegradable and enter into the food chain.

\section{Acknowledgements}

We express our sincere thanks to the scientists of the Bangladesh Institute of Nuclear Agriculture (BINA), Mymensingh-2202, Bangladesh, for considering and providing us their laboratory facilities for analyzing soil quality parameters during the study period.

\section{References}

[1] M. M. Rahman, K. R. Sultana, and M. A. Hoque, Suitability sites for urban solid waste disposal using GIS approach in Khulna city, Bangladesh, Proc. Pakistan Acad. Sci., 45(1), 2008, 11-22.

[2] A. K. Sahu, Present scenario of municipal solid waste dumping grounds in India, in Proceedings of the international conference on sustainable solid waste management, Chennai, India, 2007, 327-333.

[3] S. Charlesworth, M. Everett, R. McCarthy, A. Ordonez, and E. De Miguel, A comparative study of heavy metals concentration and distribution in deposited street dusts in a large and a small urban area: Birmingham and Coventry, West midlands, UK, Environ. Int., 29 (5), 2003, 563-573.

[4] O. A. Al-Khashman, Heavy metal distribution in dust, street dust and soil from the work place in Karak Industrial Estate, Jordan, Atmos. Environ., 38 (39), 2004, 6803-6812.

[5] K. M. Banat, F. M. Howari, and A. A. Al-Hamad, Heavy metals in urban soils of central Jordan: Should we worry about their environmental risks?, Environmental Research, 97(3), 2005, 258-273.

[6] A. R. Karbassi, S. M. Monavari, G. R. N. Bidhendi, J. Nouri, and K. Nematpour, Metal pollution assessment of sediment and water in the Shur River, Environ. Monitor. Assess., 147(1-3), 2008, 107-116.

[7] M. S. Islam and M. Tanaka, Impacts of pollution on coastal and marine ecosystems including coastal and marine fisheries and approach for management: A review and synthesis, Marine Pollution Bulletin, 48(7-8), 2004, 624-649.

[8] M. A. Satter and M. S. Islam, Quality assessment of river water around Dhaka city, Bangladesh Journal of Environmental Sciences, $10,2005,326-329$

[9] E. O. Longe and L. O. Enekwechi, Investigation on potential groundwater impacts and influence of local hydrology on natural attenuation of leachate at a municipal landfill, International Journal of Environmental Science and Technology, 4(1), 2007, 133140 .

[10] A. H. Mahvi, Application of agricultural fibers in pollution removal from aqueous solution, International Journal of Environmental Science and Technology, 5(2), 2008, 275-285.

[11] S. Suthar and S. Singh, Vermicomposting of domestic waste by using two epigeic earthworms (Perionyx excavatus and Perionyx sansibaricus), International Journal of Environmental Science and Technology, 5(1), 2008, 99-106.

[12] R. M. Harrison and M. B. Chirgawi, Sources of metals in the soil, Science of Total Environment Journal, 15, $1989,13-34$.

[13] Marzieh, Shirdast, H. Hosseini, Mirseyed, and F. Sarmadiyan, Variation in soil heavy metal concentrations around and downstream of a municipal waste landfill, in: $19^{\text {th }}$ World Congress of Soil Science, Brisbane, Australia, 2010, $225-227$.

[14] M. E. Bidhendi, A. R. Karbassi, A. Baghvand, M. Saeedi, and A. H. Pejman, Potential of natural bed soil in adsorption of heavy metals in industrial waste landfill, International Journal of Environmental Science and Technology, 7(3), $2010,545-552$.

[15] K. R. Sharma and M. Agrawal, Biological effects of heavy metals: An overview, Journal of Environmental Biology, 26, 2005, 301313.

[16] M. I. Yahaya, S. Mohammad, and B. K. Abdullahi, Seasonal variations of heavy metals concentration in Abattoir dumping site soil in Nigeria, Journal of Applied Sciences for Environmental Management, 13(4), 2009, 9-13,

[17] Banglapedia, National Encyclopedia of Bangladesh, Asiatic Society of Bangladesh, 2008.

[18] M. L. Jackson, Soil chemical analysis (Oaretic Hall of India Private Ltd., New Delhi, India, 1, 1973) 46-47.

[19] N. K. Biswas and S. I. Mukherjee, Soil Chemical analysis (Oaretic Hall of India Private Ltd., New Delhi, India, 1987).

[20] C. S. Piper, Soil and plant analysis (Adelaide University Hassel Press, Australia, 1950) 78.

[21] C. A. Black, Methods of Soil Analysis: Part 2 (Am. Soc. Agron. Inc. Madi, Wis., USA, 1965) 67.

[22] A. L. Page, R. H. Miller, and D. R. Kenny, Methods of soil analysis: Part 2, in $2^{\text {nd }}$ Edition (Amer. Soc. Agron. Inc., Wisconsis, USA, 1989) 1203.

[23] R. G. McLaren, R. S. Swift, and B. F. Quin, EDTA extractable copper, zinc and manganese in soils of the Chaterburt plain, Z. J. Agric. Res., 27, 1984, 27-217.

[24] U. Goswami and H. P. Sarma, Study of the impact of municipal solid waste dumping on soil quality in Guwahati city, Poll. Res., 27(2), 2008, 327-330.

[25] S. L. Tisdale, W. L. Nelson, J. L. Halvin, and J. D. Beaton, An introduction to nutrient management-Soil fertility and fertilizers, in $6^{\text {th }}$ edition (The Prientice Hall, New Jersey, 1999) 52-278.

[26] SRDI (Soil Resource Development Institute), Land and soil resources utilization guide, Soil Resources Development Institute, Dhaka, Bangladesh, 2001, 80-85. 
[27] P. K. Govil, G. L. N. Reddy, and A. K. Krishna, Contamination of soil due to heavy metals in the Patancheru industrial development areas, Andhra Pradesh, India, National Geophysical Research Institute, Hyderabad, India, 41(3-4), 2001, 461-469.

[28] A. Anuradha, Adsorption of copper in sewage irrigated soils, Journal of Ecotoxicology and Environmental Monitoring, 15(4), 2005, 341-345.

[29] C. H. Moon, Y. S. Lee, and T. H. Yoon, Seasonal variation of heavy metal contamination of top soils in the Taegun industrial complex (II), Environmental Technology, 12, 1991, 412-419.

[30] C. K. Jain, K. K. S. Bhattia, and S. R. Kumar, Ground water contamination in greater Guwahiti, Assam, Indian Journal of Environment and Protection, 20(9), 2000, 641-648.

[31] A. Bernard, Cadmium and its adverse effects on human health, Indian Journal of Medical Research, 128, $2008,557-564$.

[32] S. C. Barman, G. C. Kisku, P. R. Salve, D. Mishra, R. K. Shau, P. W. Ramteke, and S. K. Bhargwa, Assessment of industrial effluent and its impact on soil and plants, Journal of Environmental Biology, 22(4), 2001, 251-256.

[33] X. Xiong, F. Stagnitti, J. Peterson, G. Allinson, N. Turoczy, Heavy metal contamination of pasture soils by irrigated municipal sewage, Bulletin Environmental Contamination and Toxicology, 67, 2001, 535-540.

[34] A. Zahid, K. Balke, M. Q. Hassan, and M. Flegr, Evaluation of aquifer environment under Hazaribagh leather processing zone of Dhaka city, Environmental Geology, 50, 2006, 495-504.

[35] J. R. Peralta, J. C. Gardea, Torresday, K. J. Tiemann, E. Gomez, S. Arteoga, E. Rascon, and J. G. Paras, Uptake and effects of five heavy metals on seed germination and plant growth in Alfa (Medicago sativa L.), Bulletin of Environmental Contamination and Toxicology, 66, 2001, 727-734.

[36] A. Tsakou, M. Roulia, and N. S. Christodoulakis, Growth of cotton plant (Grossipium hirsutum) as affected by water and sludge from sewage treatment plant, Bulletin of Environmental Contamination and Toxicology, 56, 2001, 735-742. 